\section{Kognitiv atferdsterapi eller sovemedisin?}

\author{
Kognitiv atferdsterapi har god \\ effekt mot søvnløshet hos voksne \\ og mindre bivirkninger enn sove- \\ medisin, viser ny studie.
}

Mange studier tyder på at kognitiv atferdsterapi kan ha god effekt ved kronisk insomni, som er en svært vanlig lidelse. I en systematisk oversiktsartikkel og metaanalyse publisert i Annals of Internal Medicine ble 20 randomiserte, kontrollerte studier med til sammen 1162 voksne pasienter inkludert (1).

De som fikk kognitiv atferdsterapi falt i søvn 19 minutter tidligere enn kontrollpersonene (95\% KI 14-24), og ufrivillig oppvåkning etter innsovning ble utsatt med 26 minutter (95\% KI 15-37). Det ble ikke rapportert noen uønskede hendelser eller bivirkninger. Effekten vedvarte i opptil 12 måneder etter avsluttet behandling.

- Det har lenge vært kjent at kognitiv atferdsterapi har god og varig effekt på kronisk insomni, sier overlege og søvnforsker Eli Sørensen ved Nasjonal kompetansetjeneste for søvnsykdommer, Haukeland universitetssykehus. - Denne metaanalysen bekrefter at kognitiv atferdsterapi har god effekt, er uten bivirkninger, at pasientene er tilfredse og at effekten vedvarer lenge. Legemidler mot insomni virker også, men har bivirkninger, og effekten er ofte kortvarig. Derfor er det bra at både leger og pasienter minnes på at kognitiv atferdsterapi er et godt behandlingsalternativ ved søvnløshet, sier Sørensen.

\section{Martine Rostadmo}

Tidsskriftet

\section{Litteratur}

1. Trauer JM, Qian MY, Doyle JS et al. Cognitive behavioral therapy for chronic insomnia: a systematic review and meta-analysis. Ann Intern Med 2015; 163: 191-204.

\title{
Kort vei til kirurgi er avgjørende ved akutt abdomen
}

\author{
Risikoen for å dø av akutt abdomen øker betydelig hvis det er langt til \\ nærmeste sykehus med kirurgisk akuttberedskap, viser studie fra India.
}

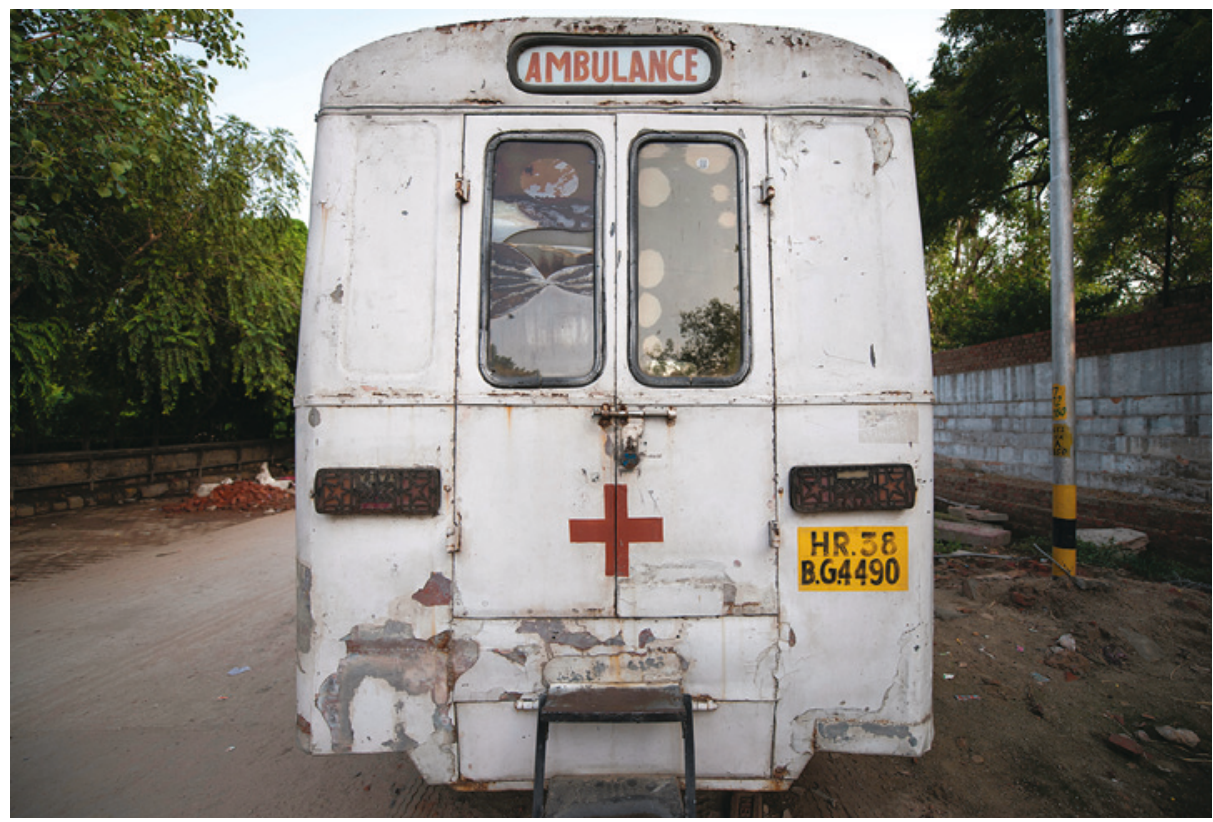

Illustrasjonsfoto: Thinkstock

Forskere ønsket å undersøke om reisevei til sykehus med kirurgisk akuttberedskap påvirket dødsårsak. I et representativt utvalg av befolkningen i India ble dødsårsak registrert i 1,1 millioner husholdninger i perioden 2001-03, og disse dataene ble koblet til geografisk nærhet til sykehus med 24 timers akuttberedskap for kirurgi (1).

$1,1 \%$ av dødsfallene i aldersgruppen 0-69 år var forårsaket av en akutt abdominal tilstand. Nær $80 \%$ av disse dødsfallene skyldtes blødning fra eller perforasjon av mage- eller duodenalsår. De fleste dødsfallene skjedde i hjemmet og i rurale områder. Kun $21 \%$ av dødsfallene skjedde på sykehus.

For akutt abdomen var det store geografiske forskjeller i mortalitetsrate. Områdene med høyest mortalitet hadde 42,6 dødsfall per 100000 innbyggere per år, mens områdene med lavest mortalitet kun hadde 5 dødsfall per 100000 innbyggere per år. Oddsratio for å være et område med høy mortalitet var 4,4 når avstanden til et sykehus med akutt- beredskap for kirurgi overskred $50 \mathrm{~km}$ i luftlinje. Tilsvarende forskjeller ble ikke funnet for mindre akutte kirurgiske diagnoser som kreft.

Forfatterne konkluderer med at om lag to tredeler av dødsfall forårsaket av akutte abdominale tilstander i India kunne vært unngått med bedret tilgang til kirurgisk akuttberedskap for alle landets innbyggere. Dersom eksisterende sykehus ble oppgradert til å ha slik beredskap, kunne om lag 50000 liv bli spart årlig, ifølge forfatterne av studien.

\section{Matilde Risopatron Berg}

Sykehuset Innlandet, Hamar

\section{Litteratur}

1. Dare AJ, Ng-Kamstra JS, Patra J et al; Million Death Study Collaborators. Deaths from acute abdominal conditions and geographical access to surgical care in India: a nationally representative spatial analysis. Lancet Glob Health 2015; 3 : e646-53.: 